\title{
CHARACTERIZATION OF UMAMI TASTE SENSITIVITY IN CHILDREN WITH AND WITHOUT CANCER
}

\author{
Ilana Elman', Ana Paula Gines Geraldo², Cristiane Karcher ${ }^{3}$, \\ Maria Elisabeth Machado Pinto-e-Silva4
}

\begin{abstract}
Introduction: The umami taste comes from glutamate and 5 ribonucleotides including inosinate and guanylate, which appear naturally in many foods. It can be identified by monosodium glutamate, being considered as a subtle taste, but blending well with other tastes, expands and enhances the flavor. Objective: to identify umami taste thresholds in children with ALL or NHL and in healthy school children and to correlate taste sensitivity with nutritional status, age and gender. Methods: The threshold sensitivity test was applied to determine umami taste using 6 solutions containing increasing concentrations of deionized water and monosodium glutamate. Subjects were weighed and measured, and BMI was calculated to determine nutritional status. For statistical analyses were used version 2.6.6 of the R Statistical software and Mann-Whitney and Kruskal-Wallis tests with descriptive levels $(p=0.05)$. Results: The sample consisted of 102 patients and 42 school children, and that subjects were male $(53.9 \%$ and $54.8 \%)$, eutrophic $(63.7 \%$ and $69.0 \%)$ and aged from 6 to 9 years $(58.8 \%$ and $52.4 \%)$, respectively. Most patients $(92.0 \%)$ and school children $(97.4 \%)$ were sensitive to umami taste and had similar umami taste threshold values. No statistically significant difference was found between umami taste thresholds of sensitive patients and school children, BMI, gender. Conclusions: Perception of umami taste was independent of gender, age, nutritional status or presence of disease.
\end{abstract}

Key words: monosodium glutamate; taste; cancer; children.

\footnotetext{
PhD. School of Public Health, University of São Paulo. Department of Nutrition

PhD Student. School of Public Health, University of São Paulo. Department of Nutrition.

Bachelors in Statistics and Masters in Engineering from the University of São Paulo.

Professor, PhD, School of Public Health, University of São Paulo. Department of Nutrition.

Declaramos que o artigo é original, nunca tendo sido publicado e, caso seja aceito pela Revista Brasileira de Crescimento e Desenvolvimento Humano - RBCDH, não será publicado em outra revsita.

Este artigo não foi e nem será enviado à outra revista enquanto sua publicação estiver sendo considerada pela Revista Brasileira de Crescimento e Desenvolvimento Humano - RBCDH.

Todos os autores participaram da concepção do trabalho, da análise e interpretação dos dados e de sua redação e revisão crítica, tendo lido e aprovado a versão final.

Não foram omitidas informações sobre quaisquer ligações ou acordos de fianciamento entre os autores e companhias ou pessoas que possam ter interesse no material abordado no artigo.

Os autores reconhecem que a Revista Brasileira de Crescimento e Desenvolvimento Humano - RBCDH passa a ter os direitos autorais, caso o artigo venha a ser publicado.

Corresponding author: ilanaelman@hotmail.com
}

Suggested citation: Elmam I, et al. Characterization of umami taste sensitivity in children with and without cancer; Journal of Human Growth and Development 2013; 23(2): 136-143

Manuscript submitted Aug 01 2012, accepted for publication Dec 192012. 


\section{INTRODUCTION}

The umami comes from glutamate and 5 ribonucleotides, including inosinate and guanylate, which appear naturally in many foods, such as meat, fish, vegetables and dairy products. The umami taste is subtle, but blending well with other tastes, expands and increases the flavor ${ }^{1}$.

Foods and ingredients rich in amino acids such as monosodium glutamate or based on protein hydrolysates (soy or fish) have been used in culinary preparations for a long time in various cultures to enhance the sensory qualities in food. In Japan, pleasant flavor enhancer was described by word umami, which means delicious ${ }^{2}$.

Acute lymphoblastic leukemia (ALL) is the most frequently occurring cancer in the pediatric population worldwide. Another high incidence child cancer is lymphoma, particularly Non-Hodgkin Lymphoma ${ }^{3}$.

In Brazil, cancer is the second most common cause of death among children aged 1 to 14 years, mirroring data for the United States, and is exceeded only by accidents and violence ${ }^{4}$.

Chemotherapy agents can cause changes in taste / smell perception, drying of the mouth, nausea and/or vomiting, which contributes to a lowering of food intake. Taste alterations and smell alterations are a frequently observed, yet understudied side effect in chemotherapy patients, considerably affecting the patients' quality of life, including children ${ }^{5,6}$. This reduction compromises nutritional status, response to treatment and quality of survival of patients 6,7 .

Food choice and acceptance of children are based on the sensory properties of the food ${ }^{8}$ and including taste, smell and psychological state of the individual ${ }^{9}$. Taste in food reflects in part the consumer's social and cultural origins, social ambitions and the cultural capital acquired, either as part of their education ${ }^{10}$.

Sense of taste results directly from detection and response to sweet, salty, sour, bitter and umami stimuli. The monosodium glutamate (MSG) identify the umami taste and is classified as a flavor enhancer ${ }^{11}$.

The consumption of industrialized food, which contains MSG, like sausages and pasta, is high among healthy children and children with cancer ${ }^{12,13}$. Studies demonstrated the importance of the sensory experience in determining pleasantness and subsequent choice of food within a meal ${ }^{14}$. Threshold test is one of the tools of sensory analysis that can measure responses to stimuli with regard to food acceptance ${ }^{15}$.

The aims of this study were: (i) to identify umami taste thresholds in groups of children with acute lymphoblastic leukemia and non-hodgkin lymphoma undergoing chemotherapy and in a group of healthy school children; and (ii) to verify the relationship among umami taste threshold and gender, age, nutritional status and presence of disease, between the study groups.

\section{METHODS}

A transversal type study was performed involving 94 pediatric patients, aged from 6 to 15 years, being treated for acute lymphoblastic leukemia (ALL) and non-hodgkin lymphoma (NHL) cancer at 2 of the most important treatment centers of cancer in São Paulo. Also participated in the study 41 healthy school children enrolled at a private school in São Paulo, of the same age group as patients.

Exclusion criteria were the presence of fever, influenza or any complication in the mouth cavity and who were unable to express themselves were excluded. Children in the induction phase of chemotherapy and/or in use of corticoids (given that they increase appetite and blood pressure) and individuals whose guardians did not sign the free and informed consent term were also excluded.

The following anthropometric measurements were taken: body weight (weighing scales accurate to $\pm 0.1 \mathrm{Kg}$ ) and height (use of stadiometer accurate to $\pm 0.1 \mathrm{~cm}$ ) were taken in duplicate, and nutritional status was assessed using the body mass index $\mathrm{BMI}^{16}$.

Nutritional status was assessed based on tables of the National Center for Health Statistics $(2000)^{17}$, and Ministry of Health percentiles $(2008)^{18}$. Cut-off points of BMI for age in children aged under 10 years and over 10 years were: $<3^{\text {rd }}$ Percentile $=$ Low BMI for age; $>3^{\text {rd }}$ Percentile and $<85^{\text {th }}$ Percentile $=$ adequate $\mathrm{BMI}$ or eutrophic; $>85^{\text {th }}$ Percentile and $<97^{\text {th }}$ Percentile $=$ overweight and $>97^{\text {th }}$ Percentile $=$ obese.

Individual tests were carried out at the institutions of treatment and at the school within a noise and smell free local, at a nice temperature and in natural light ${ }^{15}$.

The samples were prepared at the Bromatology Laboratory of the Department of Faculty of Public Health of the University of São Paulo using deionized water to make up solution, and analytical balance (Mettler Toledo) to quantify the solute. The reagent (solute) used was monosodium glutamate. Based on studies conducted by the Joint FAO/WHO Expert Committee on Food Additives (JECFA) and the Food and Drug Administration (FDA), the National Health Surveillance Agency (ANVISA) considers monosodium glutamate safe for human consumption ${ }^{19,20}$. 
Solutions of deionized water and MSG were prepared weekly and stored in $250 \mathrm{ml}$ plastic bottles, duly labeled and stored at room temperature in a ventilated place ${ }^{21}$.

The concentrations used in the present study were based on those employed by MOJET et al. (2003 and 2005) 22,23 and adapted according to the results of pre-tests performed in 20 children. The six solutions used were: $0.49 ; 0.79 ; 1.25 ; 1.99$; 3.15 and $4.98 \mathrm{~g} / \mathrm{L}$. The samples were presented in pairs (solutions and deionized water) in a series of six progressively higher concentrations whereby the taster indicated whether they detected a stimulus.

A standard solution was offered (deionized water) and children had to state if the paired samples tasted the same (non detection) or different (detection, provided the solution was identified correctly). Solutions were presented until the children detected a stimulus on two consecutive occasions, at which point the sequence was halted. The test was applied in duplicate.

Patients and healthy children that detected umami by the third solution offered, i.e. at a concentration of $1.25 \mathrm{~g} / \mathrm{L}$, were considered sensitive to the umami taste. Subsequent analyses were performed in umami-sensitive groups according to the variables: presence of cancer, treatment phase, gender, age, and nutritional status.

The data collected were stored on a Microsoft Office Excel 2007 database. The sample was characterized by distribution of the frequency of the variables with the aid of the Epiinfo statistics package (Version 6.0) ${ }^{24}$.

Statistical analyses and graphs were produced using the $\mathrm{R}$ statistical software (version 2.6.2). ${ }^{25}$ Mann-Whitney and Kruskal-Wallis tests were employed for assessing sensitivity and other variables, both using descriptive levels $(p=0.05) .^{26}$
The study was approved by the Ethics Committee of Research of the Faculty of Public Health of the University of São Paulo. The institutions in which the study was run, as well as the parents or guardians, signed the consent term pursuant to the norms of resolution $n^{\circ} 196$ of $10^{\text {th }}$ of October 1996 of the National Health Council.

\section{RESULTS}

In terms of sensitivity to umami taste, amonsg the 144 children, some detected the taste at concentrations above the average for the group and were considered outliers. This group was classified as less sensitive, and comprising eight patients $(7.8 \%)$ and one school child $(2.4 \%)$, which only detected beyond the third umami's solution offered, i.e. a concentration greater than $1.25 \mathrm{~g} / \mathrm{L}$. Thus, for the study were included 135 children who were considered susceptible to umami taste.

Most children were male (54.8\% school children and $58.9 \%$ children with cancer), eutrophic $(69.0 \%$ e $63.7 \%)$ and the majority aged between 6 and 9 years. Among those with cancer, most hsd acute lymphoblastic leukemia, and were in the maintenance phase of chemotherapy.

Among the patient population considered sensitive, 80 (78.4\%) children had Acute Lymphoblastic Leukemia and 22 children (21.6\%) had Non-hodgkin Lymphoma. No statistically significant difference was found between the groups for disease type ( $p=0.6338$ ) (Wilcoxon) and therefore all patients were pooled into a single cancer group.

The distribution of umami taste thresholds by gender of patients and school children are in Table I.

Table 1: Mean, and standard deviation of detection thresholds in children with cancer and schoolchildren by presence of disease and phase of treatment. São Paulo, Brazil. 2008/2009

$\begin{array}{cccc}\text { Variable } & \text { Mean Thresholds } & \text { Standard Deviation } & \mathbf{n} \\ \text { Cancer } & & & 41 \\ \text { No* } & 0.5812 & 0.14 & 94 \\ \text { Yes* } & 0.6306 & 0.16 & 11 \\ \text { Treatment Phase** } & & 0.15 & 83 \\ \text { Increased - Consolidation } & 0.58 & 0.17 & 41\end{array}$

Wilcoxon* $(\chi 2=1.562)(p=0.06)$

Kruskal-Wallis** $(\chi 2=4.3723)(p=0.11)$ 
The patient and healthy schoolchildren groups had similar umami taste threshold values, where the mean, third quartile and standard deviations of children with cancer were slightly higher than those of healthy children. However, no statistically significant difference was found between umami taste thresholds of sensitive patients and school children.
The children with cancer in the maintenance phase had higher median, mean, third quartile and standard deviation values than did children in the increased-consolidation phase. No statistical difference was found in. assessments of the relationship between patients at maintenance phases and healthy school children.

The distribution of the sample in terms of nutritional status was depicted in Table 2 and Graph 1.

Table 2: Mean, and standard deviation of detection thresholds in children with cancer and schoolchildren by nutritional status, gender and age. São Paulo, Brazil. 2008/2009

\begin{tabular}{|c|c|c|c|c|c|c|}
\hline \multirow{3}{*}{$\begin{array}{c}\text { Nutritional Status* } \\
\text { Eutrophic }\end{array}$} & \multicolumn{3}{|c|}{ Schoolchildren } & \multicolumn{3}{|c|}{ Children with cancer } \\
\hline & \multicolumn{2}{|c|}{ MeanStandard Deviation } & \multirow{2}{*}{$\begin{array}{l}\mathbf{n} \\
31\end{array}$} & \multirow{2}{*}{$\begin{array}{l}\text { Mean } \\
0.62\end{array}$} & \multirow{2}{*}{$\begin{array}{c}\text { Standard Deviation } \\
0.16\end{array}$} & \multirow{2}{*}{$\begin{array}{r}n \\
62\end{array}$} \\
\hline & 0.58 & 0.14 & & & & \\
\hline Obese and Overweight & 0.58 & 0.12 & 10 & 0.63 & 0.17 & 24 \\
\hline Underweight & & & & 0.70 & 0.20 & 8 \\
\hline \multicolumn{7}{|l|}{ Gender** } \\
\hline Female & 0.57 & 0.12 & 18 & 0.62 & 0.15 & 43 \\
\hline Male & 0.59 & 0.15 & 23 & 0.64 & 0.18 & 51 \\
\hline \multicolumn{7}{|l|}{$\mathrm{Age}^{* * *}$} \\
\hline $6-8$ years & 0.64 & 0.05 & 5 & 0.62 & 0.19 & 10 \\
\hline $8-10$ years & 0.58 & 0.18 & 13 & 0.59 & 0.15 & 15 \\
\hline $10-12$ years & 0.60 & 0.10 & 10 & 0.63 & 0.16 & 14 \\
\hline $12-14$ years & 0.55 & 0.21 & 5 & 0.67 & 0.19 & 36 \\
\hline > 14 years & 0.54 & 0.10 & 8 & 0.70 & 0.11 & 19 \\
\hline
\end{tabular}

Kruskal-Wallis* $(\chi 2=4.8612)(p=0.30)$

Kruskal-Wallis** $(\chi 2=3.6992)(p=0.29)$

Kruskal-Wallis*** $(\chi 2=9.1933)(p=0.41)$

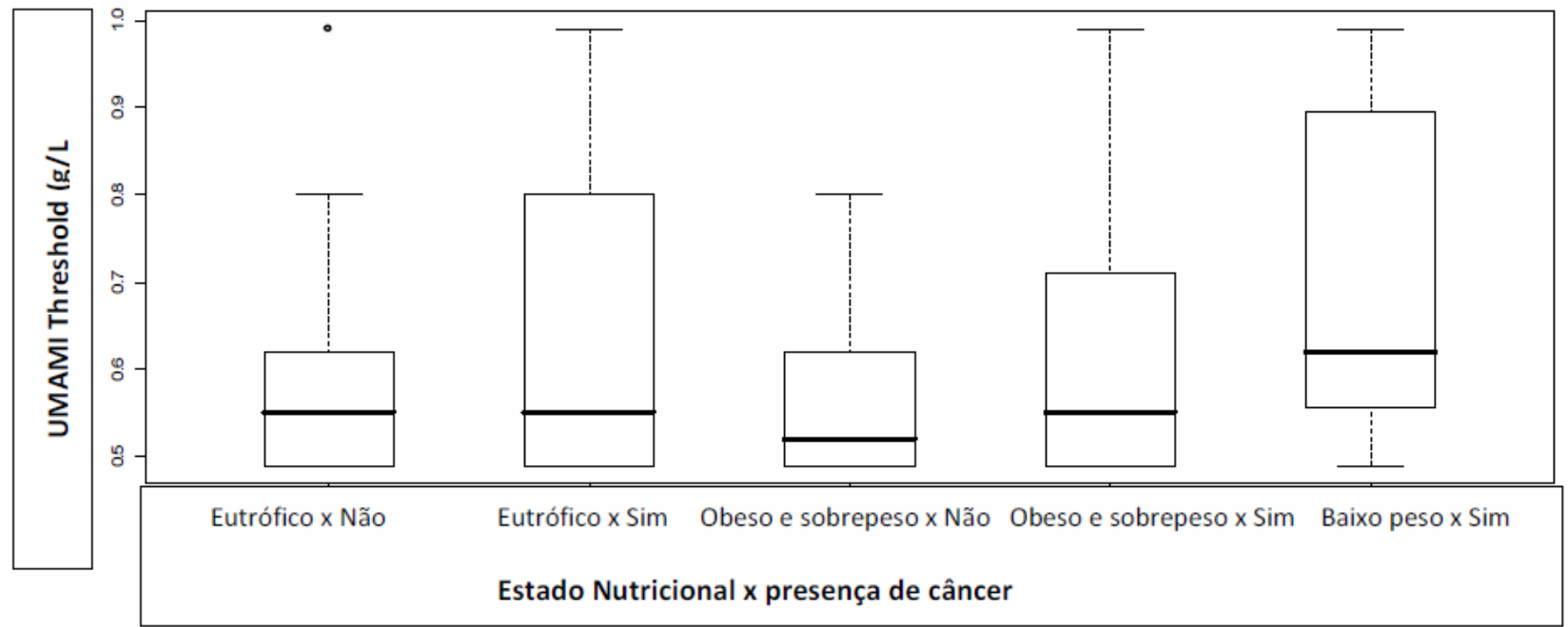

Graph 1: Distribution of umami taste thresholds by nutritional status. São Paulo, Brazil. 2008/2009 
The umami taste detection threshold according to nutritional status of patients and healthy school children were similar, while malnourished children with cancer presented higher values for first and third quartiles, mean and standard deviation, as they seems to be less sensitive to umami taste that school children.
However, on statistical analysis, no significant difference was found between umami taste detection and nutritional status.

The distribution of umami taste thresholds of patients and school children by gender are depicted in Graph 2 and Table 2.

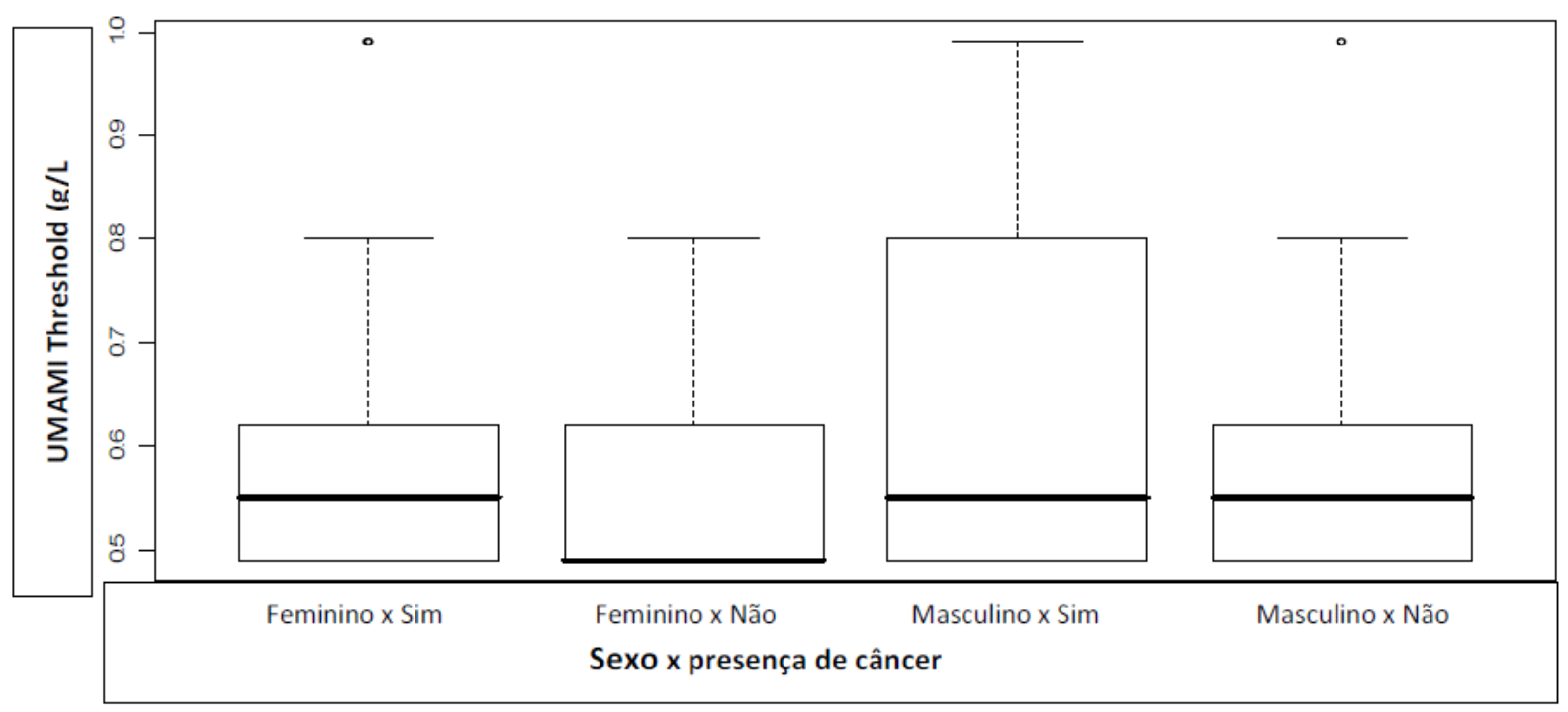

Graph 2: Distribution of umami taste thresholds by gender. São Paulo, Brazil. 2008/2009

No significant difference was found between umami taste detection and gender, but it is possible to observe a trend from the Graph II, where girls with cancer tend to be more sensitive to umami.

Analysis of the relationship among umami sensitive patients and school children and age revealed no statistical difference.

The children with cancer aged 14 years or older had higher first and third quartile and median values than the other children. As they seems to be less sensitive to umami taste that the younger children. However, analysis of the relationship among umami sensitive patients and school children and age revealed no statistical difference.

\section{DISCUSSION}

The study population comprised predominantly male children undergoing treatment for ALL (80\%). These data are in line with those of recent studies which report that ALL is the most prevalent type of cancer and more frequently found in boys ${ }^{27,28}$.

The fact that the disease has a higher peak incidence and treatment lasts an average of 2 to 3 years means that the age group $e^{\prime \prime} 6$ years-and- older has a higher number of children undergoing treatment ${ }^{18}$. This finding is also in agreement with the data of the Population Cancer Register, where the highest percentage of leukemia was found at 8 years of age in girls and 10 years of age in boys, while incidence of lymphoma peaked at 10 years in boys and 4 years in girl ${ }^{3}$.

Lymphoma is the second most frequent childhood cancer after leukemia, with an incidence of $11.3 \%$ in minors under 15 years of age, whereas the non-hodgkin type is the most frequent in childhood cases, having an incidence of around $60.0 \%{ }^{3}$.

With regard to treatment phase, the majority of patients were in the maintenance phase at the time of the study, given this stage of treatment is longer than the others described in the protocols used.

The distribution of the study population in terms of nutritional status is in accordance with the results obtained by ELMAN and PINTO e SILVA ${ }^{29}$ whose study assessing 40 children with acute lymphoblastic leukemia found $7.5 \%$ of children to be underweight, $65.0 \%$ eutrophic and $27.5 \%$ overweight or obese. Although the study involved a population with disease, the findings mirrored the pattern found in healthy populations, according to the recent study ${ }^{30}$. 
Among children without diseases, school children have shown overweight as could be seen in a recent study conducted in a private school in Taubaté, São Paulo, where excess of weight was observed in $43.4 \%$ of the sample, being considered a high rate among the population ${ }^{30}$.

The group of school children had a similar age and gender distribution to the children with cancer. However, in terms of nutritional status, there were no malnourished and a higher percentage of overweight children in the healthy group compared to the cancer group. The group of children with cancer showed malnourished $(8.8 \%)$ and this can be related with the treatment or economic status. Children with cancer showed $27.4 \%$ of overweight/ obese and this can be related with drugs, like corticoids that may mask the nutritional status.

No differences were detected that were able to determine the sensitivity to umami between the two groups (with cancer and healthy). This may be due to the fact that children, regardless of disease, present your food intake based on the joy that provide food, and nutritional value comes as a result ${ }^{31}$. Thus during childhood preferences and food aversions are developed and possibly knowledge sensitivity to basic tastes.

In 2007, Bossola et al. ${ }^{31}$ suggested that cancer patients, similar to healthy individuals, were able to distinguish easily among the five concentrations of each additive (sweet, sour, bitter and salty) in the beverages and that their taste sensitivity was not reduced.

\section{REFERENCES}

1. Umami International Center and International Glutamate Information Service. The fifth taste of human being umami: the world. London: Cross Media; 2004.

2. Bellisle F. Glutamate and the Umami taste: sensory, metabolic, nutritional and behavioural considerations: a review of the literature published in the last 10 years. Neurosc Biobehav Rev. 1999; 23(3):423-38.

3. INCA - Instituto Nacional do Câncer. Estimativas 2008: Incidência de Câncer no Brasil. Rio de Janeiro: INCA, 2007. 96 págs.
Children in age group studied use to consume industrialized food, which is rich in glutamate. The dietary habits of healthy children and children with cancer are similar, thus no differences were found, since the consumption of foods was similar for both groups. The eating habits of healthy children and children with cancer are similar, so no differences were found, since food intake was similar for both groups.

Nutritional counseling is required for this age group. Children with diseases deserve attention to monitor any deviation in food intake and receive nutritional intervention adequate to not harm the treatment, growth and development. However, children with diseases may change their appetite, limiting the intake of nutrients and calories. This change in consumption pattern can impact the nutritional status and, in the case of children with cancer, affect the recovery rate.

No statistically significant difference was found between umami taste thresholds and presence of cancer, gender, age, and nutritional status. Thus, in this study population, these variables were not factors determining umami taste detection or influencing sensitivity.

\section{Conflicts of interest}

This study was conducted with the financial support from the Fundação de Amparo á Pesquisa de São Paulo (Fapesp), process n 06/59460-7, as part of a PhD thesis at the Faculty of Public Health of the University of São Paulo.

4. Chatenoud L, P Bertuccio, Bosetti C, et al. Childhood Cancer Mortality in America, Asia, and Oceania, 1970 Through 2007. Câncer. 2010;116(21):5063-5074.

5. Gamper EM, Zabernigg A, Wintner LM, et al. Coming to Your Senses: Detecting Taste and Smell Alterations in Chemotherapy Patients. A Systematic Review. J. Pain Symptom Manage. 2012; 44(6): 880-895.

6. Ravasco P. Aspects of taste and compliance in patients with cancer. Eur J Nurs Oncol. 2005; 9 (Suppl 2): S84-S91.

7. Chao-Hsing Yeh, Chao-Hui Wang, Yi-Chien Chiang, Lin Lin, et al. Assessment of symptoms reported by 10 - to 18 -year-old cancer patients in Taiwan. J. Pain Symptom Manage. 2009; 38 (5): 738-746. 
8. Sosa M, G. Sensory acceptability of menus and sweet snacks among children and adults from low- and medium-income households in Argentina. Food Quality and Preference. 2006; 17(7-8): 590-597.

9. Ninomya K, Rozin E. Umami Internacional Center. The fifth taste of human being umami: the world. Londres: Cross Media Limited; 2007. 80 págs.

10. Wright LT, Nancarrow C, Brace I. Researching taste: layers of analysis. Br. Food J. 2000; 102 (5-6): 429-440.

11. Ninomya K, Rozin E. Umami Internacional Center. The fifth taste of human being umami: the world. Londres: Cross Media Limited; 2004.

12. POF - Pesquisa de Orçamentos Familiares 20082009: despesas, rendimentos e condições de vida. Rio de Janeiro: Instituto Brasileiro de Geografia e Estatística - IBGE; 2010.

13. Pinto-e-Silva MEM, Paton I, Trigo P, et al. Perfis socioeconômico e nutricional de crianças e adolescentes com câncer. Rev Bras Nutr Clin. 2004; 19 (3):123-127.

14. Hetherington MM, Bell A, Rolls BJ. Stimulus satiation: effects of repeated exposure to foods on pleasantness and intake. Br J. Food 2000; 102 (7) : 507-521.

15. ABNT - Associação Brasileira de Normas Técnicas. Teste de sensibilidade los Análise sensorial: NBR 13172. São Paulo, 1994.

16. Lochman TG, Roche AF, Matorell R. Anthoropometric standardization reference manual. Champaign: Human Kinetics Publishers; 1988. 90 págs

17. NCHS - National Center for Health Statistics. Advance data from vital and health statistics of the Centers for Disease Control and Prevention. Atlanta; 2000. p.1-27.

18. Ministério da Saúde. Orientações para à Coleta e Análise de Dados antropométricos dos
Serviços de Saúde. SISVAN: Vigilância Alimentar e nutricional. 2008. Disponível em URL: http://www.sisvan_norma_tecnica_ preliminar_criancas.pdf. [Acessado 25 de setembro de 2010].

19. ANVISA - Agência Nacional de Vigilância Sanitária. Resolução no 386, de 5 de agosto de 1999. Regulamento Téc. Sobre Aditivos utilizados segundo a Boas Práticas de Fabricação e Suas Funções. [Acesso em 05 de outubro de 2010]. Disponível em: http:// www.anvisa.gov.br/legis/resol/386_99.htm..

20. Beyreuther K, Biesalski HK, Fernstrom JD, et al. Consensus meeting: monosodium glutamate - an update. Eur J Clin Nutr. 2007; 61(3): 304-313.

21. Faria de EV, Yotsuyanagi, K. Técnicas de Análise sensorial. 2 ed. Campinas: ITAL, 2008. 116 págs.

22. Mojet J, Heidema J, Christ-Hazelhof E. Taste perception with age: generic or specific losses in Supra-threshold intensities of five taste qualities? Chem Senses. 2003; 28(5): 397-413.

23. Mojet J, Heidema J, Christ-Hazelhof E. Taste perception with age: pleasantness and its relationships with threshold sensitivity and supra-threshold intensity of five taste qualities. Food Quality and Preference. 2005; 16: 413-423.

24. Epinfo 6.0- [acesso 15 ago 2010] Disponível em: http://www.cdc.gov/epiinfo/epi6/ ei6dnjp.htm.

25. The R Project for Statistical Computing. Version 2.6.2. Boston, 2010. [acesso 20 abril 2010]. Disponível em: http://www.r-project.org.

26. Conover WJ. Práticas Estatísticas não paramétricas. 3nd ed, Nova Iorque: John Wiley \& Sons, 1998. 584 págs.

27. Reis RS, Santos MO, Thuler LCS. Incidência de tumores no Brasil. Rev Bras Cancerol. 2007; 53(1): 5-15. 
28. Elman I, NS Soares, Pinto-e-Silva MEM. Análise da sensibilidade do gosto umami em crianças com câncer. Revista Bras de Cancerol. 2010; 56(2): 237-242.

29. Elman I, Pinto-e-Silva MEM. Crianças portadoras de leucemia linfóide aguda: análise dos limiares de detecção dos gostos básicos. Rev Bras Cancerol. 2007; 53 (3): 297-303.
30. Geraldo APG, MEM Pinto-e-Silva. Alimentos processados tem alimentação infantil: análise da memória visual de escolares em Taubaté cidade, São Paulo. Rev. Bras. Crescimento desenvolv. hum. 2012, 22 (1): 53-59.

31. Bossola M, G Cadoni, Bellantone R, et al. Taste intensity and hedonic responses to simple beverages in gastrointestinal cancer patients. Pain Symptom Manage. 2007; 34 (5): 505-512. 